\title{
LOANS OF WORD IN SYNONYMY OF THE TATAR LANGUAGE
}

Kasemu Shermaymayti ${ }^{1}$

Alfiya Sh. Yusupova ${ }^{2}$

Elvira N. Denmukhametova ${ }^{3}$

Ayşen Uslu Bayramli ${ }^{4}$

Abstract: The vocabulary of each language consists of words that enable people to call the things they see and express their attitude towards them, characterize and compare them with the others. To do it, one uses lexical and grammatical means of native language and the borrowed ones from other kindred languages and unrelated languages. If in the beginning these "foreign" words are perceived as exoticisms, with time, without suspecting of their foreign origin, they can enter into its active lexical fund, take a place in dictionaries, be actively used in oral and written speech. However, they may be forgotten, not accepted by the canons of the language, or become archaisms and historicisms. The relevance of the study is explained by the tasks of revealing the role of the activity of loan words with the synonymy of the
Tatar language. The article presents the materials that reflect the experience of research of the teachers of the Kazan Federal University in cooperation with the colleagues from other countries on the study of Turkic languages, including the Tatar language in synchrony and diachrony. It is well known that the etymological affinity of the borrowed lexicon from different languages is not the same, as well as their morphological and semantic features. If the most active words are the words related to nouns and adjectives, then verb forms in Turkic languages are rarely borrowed. This paper aim is a lexico-semantic description of the synonymous connections of the verbs with borrowed stems in the Tatar language, as one of the representatives of the Turkic world. During the research, the authors got insight into modern works of Russian

\footnotetext{
${ }^{1}$ Kazan Federal University.

${ }^{2}$ Kazan Federal University.

${ }^{3}$ Kazan Federal University. denmukhametova@gmail.com

${ }^{4}$ Beykent University.
} 
and foreign authors on linguistics, philology; analyzed the lexical material fixed in bilingual dictionaries and in "The Dictionary of Synonyms" of the Tatar language; made comparisons of the dictionary fund and practical Tatar speech; revealed the basic tendencies of development of the modern literary language.

Keywords: synonyms, the Tatar language, dictionaries, speech, Turkic languages, loan words.

\section{Introduction}

At present, the world is so intertwined that it is sometimes difficult to determine and establish the boundaries between primordially linguistic means and borrowed ones. To use in speech, it may not be so important to know the etymology and genetic characteristics of a lexeme. Phonetic composition, grammatical categories and stylistic possibilities of native lexemes and borrowed ones do not always coincide and have restrictions concerning their use in speech. This is particularly pronounced in respect of the stylistic and lexical-semantic aspects. However, these restrictions with time are reduced and loan words are increasingly being used in the language.

The object of this investigation is synonymous rows of the verbs that contain loan lexemes as the indicators of borrowing foreign words in the Tatar language.

The subject of the study is synonymous bonds between the originally Tatar, common Turkic and borrowed verb stems, their structural specificity and peculiarities of use in the Tatar speech.

The aim of the work is lexicosemantic studies of synonymous connections of verbs with borrowed stems in the Tatar language, as the most complex and uncharacteristic forms for the Turkic languages.

Reasoning from the goal, the following tasks are formulated:

1. to dentify the structural specificity of synonymic rows of verbs with borrowed stems;

2. to define the possibility of interchangeability of such synonyms in the flow of speech;

3. to consider the possibility of replenishment and reduction of lexemes in the synonymic rows of verbs in the 


\section{Periódico do Núcleo de Estudos e Pesquisas sobre Gênero e Direito \\ Centro de Ciências Jurídicas - Universidade Federal da Paraíba \\ V. 8 - No 04 - Ano 2019 - Special Edition}

ISSN | 2179-7137 | http://periodicos.ufpb.br/ojs2/index.php/ged/index

dictionary of synonyms of the Tatar language;

4. to reveal lexico-semantic features of borrowed verbal synonymous forms in the literary and folklore texts.

The source of the study is the dictionary of synonyms of the Tatar language [1]. The actual research material is taken from the National Corpus of the Tatar language "Tugan tel" [ http://litcorpus.antat.ru/index.htm] and the Corpus of Tatar Literature [http://litcorpus.antat.ru/index.htm].

It is well known that the issues of lexical synonymy were studied theoretically and practically in numerous works of domestic and foreign scholars. They inquire into general questions of the development of the language system and describe the particular forms of enrichment of a particular language, analyze the changes in its lexical fund based on extralinguistic and interalinguistic factors of speech, give linguistic and sociocultural characteristics to the vocabulary of the language in connection with the above reasons. When preparing this article, the analyses of the dictionary fund of the Tatar language as one of the ancient representatives of the Turkic languages fixed in its dictionaries [2,3,4] were considered, the materials investigated on the basis of the paroemiological foundation were studied [5], the researches of the colleagues based on the language teaching were analyzed [6,7], relying on the works of scientists who studied the dialect material of the Tatar language [8], the results of the influence of extralinguistic factors on the borrowing of lexemes from the Arabic, Persian, ENGLISH and European languages with the general development of the Tatar language in the Russian Federation were compared [9].

If by now the borrowed vocabulary in the Tatar language has been studied by individual scholars, the verbal forms in the lexical synonymy of the Tatar language have not been the object of certain studies to this day, which explains the relevance of this work.

\section{Methods}

In the context of this paper, the method of statistical data analysis, the method of seme analysis, the method of comprehensive component analysis, the method of etymological analysis were used. The methodological basis of the research is: the activity approach that 
determines the unity of activity and consciousness; the axiological, culturological, hermeneutical approaches, allowing to interpret the lexical and semantic features of the loan words in the Tatar linguistic environment.

\section{Results and discussion}

In Tatar linguistics, the study of the verb as a part of speech was covered by the numerous works of the Tatar enlighteners and scholars. The research papers by I. Giganov, M. Ivanov, A. Kazem-Beck, K. Nasyri, Sh. Akhmerov, G. Nugaybek, V. Khangildin, D. G. Tumasheva, F. A. Ganiev, K.Z. Zinatullina, F. M. Khisamova, and others have concerned the verb forms and grammatical categories in respect of various aspects. As pointed out by scholars, as a rule, in the Tatar literary language, verb forms were not borrowed from other languages, therefore, nonderivative verbs consist only of originally Turkic-Tatar words. However, as stated in the Tatar grammar, the verbs in Turkic languages can be structurally both analytical and synthetic [10: 82-83]. At the same time, derivative verbs can have both an originally Turkic-Tatar
408

basis and the one borrowed from other languages. Verbs of suffix derivation in the Tatar language make up the largest part in the structural system of verb formation, although many of the borrowed word stems are transformed into a verb in a syntactic-morphological way, that is, by adding stems.

The "Tatar Grammar" indicates 14 productive suffixes in modern verb building [10: 86]. As research has concluded, "The Dictionary of Synonyms" of the Tatar language unites over 25000 words in more than 4500 synonymous groups. It fixes 1832 verbal synonymous groups. Of these, only $1 / 3$ (611) contains the words with borrowed stems, although in colloquial speech and in the literary language there are a lot more such verb forms. If to compare with other parts of speech, the synonymous groups of nouns, which comprehend the borrowed words from Arab-Persian or Russian, European languages, make up 3242 units, and the names of adjectives 2342.

It should be noted that most of the verbs with the borrowed stems fixed in the dictionary are the words of Arabic and Persian origin. For example, ziyan киги (понести убыток, ущерб / to 
sustain damages) - kaza kuru, kaza kilu, zarar kuru, ziyanlanu, zarar-zekhmet kиги; kuchsizlenи (слабеть, обессилить, терять силу / to sap one's strength) - khelsezlenu, jeger sezlenu, kuch betu, kuchsez kalu, kuch kitu, kuch yugaltu, khel kitu, khel yugalu,khel betu, khelsez kalu, jeger betu, jegersez kalu, quet betu, gayret betu, yomshaw, buinsizlanu, gayret shinu, zegiflenu; khuplaw (одобрять, считать достойным, подходящим / to approve/ to consider to be worth/ appropriate) khup kuru, khup sanaw, yakhshi dip tabu, qulay sanaw, qulay kuru, qulay dip tabu, yaraqli sanaw, yaraqli tabu, unay karaw, layik sanaw, layik dip tabu, alqishlaw, alqishlap qarshilaw, muafik dip tabu, megqul kuru, quetlew, joplew, kabul itu, khush kuru, khushlaw.

As the above synonymous rows illustrate, in most of them there are the verb forming stems from Arabic (kaza убыток; zarar - вред, zekhmet болезнь, вред, khel - сила / strength, quet - мощь / power, gayret - воля / will, khup - любимый / beloved, хороший / good, layik - достойный / deserving, muafik - пригодный / suitable, megqul - должный / due, Kabul - принимающий / receiving) and from Persian (ziyan - вред / harm, jeger - мощь / might, zegif - обиссиленный / exhausted) words. They are used in Tatar with different shades of one and the same meaning of the word.

Verb forming stems - the lexemes from the Russian language or international vocabulary are far less, although in modern colloquial speech and language of journalistic texts they can be frequent. For example, khosusiylashtiru (приватизировать / to privatize) - privatizatsiyalew; fotoga toshu - suretke toshu, resemge toshu.

It has been revealed that the most productive suffixes in verb derivation are the suffixes - la/-le; -lash/-lesh; -lan/-len. Verbal compounds are produced from the borrowed stems by means of such auxiliary verbs as it, bul, qil, kil, yasa, al. They occur in the following synonymous groups: gaeplew (винить, обвинять, предъявлять обвинение / blame, accuse, arraign) - gaep tagu, gaep tashlaw, gaep itu, gaeple sanaw, gaeplege chigaru; dewalaпи (личиться) - darulanu; duslshu (сдружиться, подружиться / become friends) duslanu, eshnelenu, eshneleshu, beleshlenu, taniship kitu, tatulashu, kileshu, yoreshy. 
It should be noted that there are synonymic rows consisting of the verbs where only the loan words constitute the verb-forming basis, although most of the synonymous groups consist of mixed lexemes. For example, ilhamlanu (вдохновляться, воодушевляться / to feel inspired) - ilham kilu, ilham keru, rukhlanu, rukh kuterelu, dertlenu, dert keru, janlanu, jan keru; mikhnet chigu (cmpadamb / to suffer) - mikhnetlenu, gazap chigu, mikhnet kuru, nuja kuru, nuja chigu, nujalanu, gazap chigu, gazap kuru, gazaplanu, jafa chigu, jafalanu, izalanu, iza chigu.

It should be noted that among the adjectives such synonymous groups are a lot more. $1 / 3$ of the synonymic rows consists only of such lexemes.

The loan words such as synonyms are used in speech with different frequency, but their activity depends on stylistic coloring but not on etymological features. For example, Isenleshmi soyleshsen, awirmi ulersen (Proverb), Doshmaninni uzennen kuchle khisaplama (Proverb), Ele kupten tugel gene olke komiteti instruktori ani rayondaideologiya eshenen artta kaluwi ochen gayiplamakchi buldi. (F. Sadriyev); Hich yugi, khurla jirni. ( $R$.
Gatash); I efende, yaqinraq kil, asha hem gayep itme, bezne, bez bit sinen ni asharga telegenenne belmibez, -dide. (Fair-Tale), Awil chikkanchi khur itmese inde. ( A. Timergalin), etc.

It has been revealed that compound verbs are more actively used among derivatives of verbs from borrowed stems. They can enter into a synonymous relation with native Turkic verbs and derivative verbs formed with the help of different suffixes from the same stems. For example, from the stem isep (счет / count) - iseplew, isepleshu, isep itu, khisaplaw, khisap totu; от основь khormet (уважение, почет / respect) khormetlew, khermet itu, khermet qilu, khormet kursetu; from the stem gaep (вина / guilt)-gaeplew, gaep itu, gaеp qilu; from the stem dus (dpyz / friend) duslanu, duslashu, dus itu, dus bulu and so on.

Such verb forms in the texts are used to avoid tautology and to render stylistic coloring. For example, Shul konnen alip elege qarchiq Nim belen Num oyene kerep chigip yori bashliy, hem ana kilgen sayin qader khormet kurseteler. (Fair-Tale); Alar da ani yaratalar, khermet iteler. (R. Sibat); Drama bashlanir aldinnan, avtorni 


\section{Periódico do Núcleo de Estudos e Pesquisas sobre Gênero e Direito \\ Centro de Ciências Jurídicas - Universidade Federal da Paraíba \\ V. 8 - No 04 - Ano 2019 - Special Edition}

ISSN | 2179-7137 | http://periodicos.ufpb.br/ojs2/index.php/ged/index

khormetlew tantanasi buldi. $(R$.

rows of verbs by having added active

Nezhmiyev); Duslaru jiyilip khormet vocabulary for now. For example, one qildilar (V.M.).

Investigating synonymous rows, fixed in the dictionary, it can be noticed that in some of them there are also such verbal forms, which in the modern literary language are already archaic. For example, khuplaw (одобрять, считать достойным, подходящим / approve, to consider deserving, suitable) - khup kuru, khup sanaw, yakhshi dip tabu, qulay sanaw, qulay kuru, qulay dip tabu, yaraqli sanaw, yaraqli tabu, unay qaraw, layik sanaw, layiq dip tabu, alqishlaw, alqishlap qarshilaw, muafiq dip tabu, megqul kuru, quetlew, joplew, qabul itu, khush kuru, khuslaw. The lexemes such as khup sanaw, muafik dip tabu, megqul kuru could be excluded from this synonymic row, since they are found only in old Tatar texts or in religious texts.

The last lexeme in the synonymous row moher sugu (ставить печать/ to stamp) - moher sugu, pechat basu, pechat basu, pechatlew, keleymelew, which is a historicism, is considered to be superfluous.

At the same time, there is the possibility of replenishing synonymous could add the lexeme kipek bulu to the synonymous row with the dominant mokhtaj bulu (нуждаться / need); the lexeme rokhset itmew - to the synonymous row with the dominating lexeme tiyu (сдерживать / to hold).

Such examples are active in both written and spoken language.

\section{Summary}

The research and observation of the synonymous system of the Tatar language allowed for making the following conclusions:

1. Each language, being a complex system, has practical representation in speech and, therefore, varies depending on extralinguistic and inter-linguistic factors.

2. Loan words form a part of the synonyms of the Tatar language, as well as of any other, but when they are used in speech, the internal laws of the language act to direct our attention to the stylistic features of the language of a borrowing.

3. When teaching the Tatar language as a foreign language, we draw our focus on the dialogical forms that are 
closest to colloquial speech, as well as on the forms of monologic speech with the help of which the students report on the events of reality, by entering into communicative contact.

4. In the modern world, due to the orientation towards globalization, the tendencies towards the internationalization of the lexical fund are more often frequency. However, the Turkic languages try to keep to their linguistic canons, and to attribute their own linguistic features to the lexemes being borrowed. This is particularly pronounced in the synonymy of the Tatar verbs. Therefore, when teaching the Tatar language, it is necessary to put emphasis precisely on these properties of the language to have an effective result.

\section{Conclusions}

Thus, the synonymous system of the Tatar language, like any other, has been developing and changing, which is reflected in both spoken and written language. Concerning this, we can also insist upon the verbal synonymous groups. Although the Turkic verbal system is relatively stable, innovations in social and social life, progressive technologies make their changes to this system. Therefore, one needs to be able to use dictionaries of synonyms and choose stylistically correct lexemes.

\section{Acknowledgements}

The work is performed according to the Russian Government Program of Competitive Growth of Kazan Federal University.

\section{Bibliography}

Khanbikova Sh. S., Safiullina F.S.

Sinonimnar suzlegi.- Kazan:

Kheter, 1999. 256. Khanbikova

Sh. S., Safiullina F.S. The

Dictionary of Synonyms. - Kazan: Хэтер, 1999. 256 р. (in Tatar)

Sibgaeva, Firuza Ramzelovna; Zamaletdinova, Gulnara

Fandasovna; Nurmuhametova, Raushaniya Sagdatzyanovna Llinguoculturological specific features of phraseological units of the tatar language // Modern Journal of Language Teaching. - 
2016. Special Issue (December 2016). - Pp. 116-119
Management, 2016, Vol. 10(21), pp. 5107-5109
Yildiz, T; Diri, B; Yildirim, S. Turkish synonym identification from multiple resources: monolingual corpus, mono/bilingual online dictionaries, and WordNet. // TURKISH JOURNAL OF ELECTRICAL ENGINEERING AND COMPUTER SCIENCES. 2017, N. 25 vol. 2 pp.: 752-760.

Apresjan, V; Mikulin, N. Dictionary as an Instrument of Linguistic Research.// PROCEEDINGS OF THE XVII EURALEX INTERNATIONAL CONGRESS: LEXICOGRAPHY AND LINGUISTIC DIVERSITY. 2016, pp.: 224-231

Denmukhametov, R.R., Mugtasimova, G.R. Toponymic field of tatar folk riddles. // International Business
Kurt, Berker Analysis of Turkic Students Verbal Expression Studies in Turkey Turkish Language by "Speaking Skill Assessment Scale" / TARIH KULTUR VE SANAT ARASTIRMALARI DERGISIJOURNAL OF HISTORY CULTURE AND ART RESEARCH, 2017, Vol. 6, No. 2, pp. 358-384.

Yordanova, Milena TURKISH LANGUAGE TEACHING AT UNIVERSITIES IN BULGARIA ACTUAL STATUS AND PERSPECTIVES//

STRATEGIES FOR POLICY IN SCIENCE AND EDUCATIONSTRATEGII NA OBRAZOVATELNATA I NAUCHNATA POLITIKA. 2017, Vol. 25, N. 2, pp.: 137-142 
Radif Zamaletdinov, Guzel

Faizullina. Nominations of Person

with Name-Food Components in

Tatar National Dialects of Tyumen

Region // International Journal of

Humanities and Cultural Studies

(IJHCS) August 2016 Special

Issue,. P. 218-22.

Khanova, Zulfiya Gabdelbarovna;

Kirillova, Zoya Nikolaevna;

Alkaya, Ercan. History and

Current State of Tatar Language

Teaching in the Republic Of

Tatarstan // Revista Publicando,

Vol. 4, No 13. (1). 2017, pp.1038-

1045

Tatarskaya grammatical. T.2

Morfologiya. - Kazan: Tatarskoye

knijnoe izdatelstvo, 1993. -397. Tatar

Grammar. V.2. Morphology. - Kazan:

Tatar Book Publisher, 1993. - 397 p. (in

Russian) 